\title{
Impelementation of Problem Based Learning with Electronic Media on Student Learning Outcomes in Indonesia's - Philippines International Class
}

\author{
Nuris Fattahillah ${ }^{1)}$, Slamet Hariyadi ${ }^{2)}$ \\ Faculty of Teacher Training and Education, University of Jember, Indonesia. \\ e-mail: sayanurisfattah@gmail.com
}

\begin{abstract}
The curriculum in Philippines different with the curriculum in Indonesia. This make the learning process and the problems faced by students in Indonesia and Philippines different. One of the problems experienced by students is caused by the lack of variation in strategies in the teaching and learning process. The instructional model used by the teacher is to upgrade student learning outcomes, especially on high-level cognitive, in this research especially problem solving abilities. Instructional method used by researchers is Problem Based Learning (PBL) with a pretest posttest design. Data of this research obtained quantitatively and using the mean before and after the test. This study used control class and experimental class on material cells to organism. The results show that the experimental class has a higher average value of 88.6 compared to the control class, 81.9. These results indicate that PBL successfully increases learning activities and students can follow the learning model using PBL.
\end{abstract}

Keywords: Philippines, $P B L$.

\section{INTRODUCTION}

Indonesian education is very different from education in the Philippines. Education in the Philippines uses K-12 curriculum. K12 basic education curriculum consists of kindergarten, elementary school for grades 1-6, junior high school for grades 7-10, and high school for grades 11-12. K-12 has a program covering kindergarten and 12 years of basic education (six years of basic education, four years of junior high school, and two years of high school (SHS) to provide sufficient time for mastering concepts and skills, developing lifelong learners, and preparing graduates to higher education, mid-level skills development, employment, and entrepreneurship (K12 Phiilippines, 2018).

Students gain in-depth knowledge, skills, values, and attitudes through continuity and consistency at all levels and subjects. Discussions on issues such as Disaster Risk Reduction (DRR), Adaptation to Climate Change, and Information \& Communication Technology (ICT) included in the curriculum are enhanced. The subjects are taught from the simplest concepts to more complicated concepts through grade levels in spiral development (K12 Phiilippines, 2018).

Baguio City National High School (BCNHS) is a public education institution in Baguio City which was founded in 1916 as the Baguio Trading School. Three years after that, the name was changed to the Provincial Mountain High School (MPHS). At present, the school consists of one main campus on Govack Road and annexes located on Hillside and Fort del Pilar. BCNHS offers high school programs that serve students from Grades 7-12. High School Tracks (SHS) are offered including Academic, Vocational-Livelihoods (TVL), Arts and Design, and Sports. In addition to the offer, the school also has a Special Program (SP) in Journalism, Sports, and Arts and an Open Middle School Program (OHSP) for those who cannot attend regular classes (BCNHS, 2018).

BCNHS is the largest public school in Baguio City, Philippines. However, BCNHS has obstacles in the learning process because this school has many students for each class. Each class consists of 50 to 54 students. Based on observations made by researchers

Bioedukasi Vol. XVII. No. 1 April 2019

Received 14 February 2019| Received in revised form 15 March 2019| Accepted 29 March 2019| Published online 1 April 2019 
on August 2, 2018 towards 4 classes VII namely Masinop, Makakalikasan, Maasahan and Masipag showed a lack of effective learning due to lack of variations in learning strategies in this case the learning model used by teachers to facilitate student learning outcomes, especially high cognitive outcomes namely problem solving. The thinking ability at a high level with cognitive learning outcomes is closely related to students' initial abilities. According to Gagne (1988) in Magdalena (2015) The ability to think at a higher level requires rules that students already have that are nothing but the initial abilities. According to Lee (1999) in Magdalena (2015) Through contextual learning has the opportunity to achieve high-level thinking skills because learning is contextualized with students' daily lives.

One effective method is Problem Based Learning. Problem Based Learning is a learning approach that uses real world problems as a context for students to learn about critical thinking and problem solving skills, and to acquire essential knowledge and concepts from subject matter. Problembased learning is used to stimulate high-level thinking in problem-oriented situations, including learning how to learn. The role of the teacher in problem-based learning is to present problems, ask questions, and facilitate investigation and dialogue. Problem Based Learning is a learning model that involves students to solve problems through the stages of the scientific method so that students can learn the knowledge related to the problem and at the same time have the skills to solve problems. Problem Based Learning is a learning process that is the starting point of learning based on problems in real life and then from this problem students are stimulated to study this problem based on new knowledge and experience (Maryati, 2018).

Problem Based Learning (PBL) is an effective approach to teach high-level thinking processes with problem-oriented situations, including learning how to learn. According to Santyasa (in Ghofur: 2013), Problem Based Learning (PBL) is a strategy or approach designed to help the learning process in accordance with the steps contained in the problem solving pattern, starting from analysis, planning, solving, and inherent assessment at each stage. Problem based learning (PBL) is not compiled to help teachers convey a lot of information but the teacher as a problem presenter, questioner, and facilitator.

The learning process in the cells to organism and level of organization material teachers manage learning by providing explanations in learning, which is dominated by learning is the teacher with reference to the material prepared by the teacher. The task of learning is usually given at the end of learning in the form of individual tasks, namely assessment of cells to organism. So the interaction process in learning does not occur or rarely occurs in multiple directions, because what happens is only from teacher to student to teacher. Interactions between students and students never occur.

The results of the teacher analysis, especially in cell to organism learning from the results of assignments and other achievements, for example through tests, it turns out students experience problems in cognitive learning outcomes in problemsolving abilities included in high-level cognitive learning outcomes namely analysis (C4), evaluation (5) and creativity (C6). Students will arrive at problem solving skills if they have the ability to analyze, evaluate and creativity. Starting from this problem so that the teacher in cell to organism learning, wants to try the problem based learning (PBL) learning model which is one of the learning models so that contextual learning occurs, through the experimental class and control class procedures.

\section{RESEARCH METHODS}

\subsection{Time and Place of}

This research was conducted from July to August 2018. The place for conducting the study was in Baguio City National High School, Baguio City, Philippines.

2.2. Operational Variables and Definitions

This study consists of two variables, namely the independent variable and the dependent variable. The independent variable is the problem based learning $(\mathrm{PBL})$ 
learning model with video media and power points, while the dependent variable is the student learning outcomes after the learning process using PBL (Class VII-Masinop) and does not use the PBL learning model (Class VII-Maasahan).

Operational Definition To describe more clearly the problems to be examined, the author needs to formulate an operational definition, namely as follows:

According to Arends (Tritanto, 2007), problem based learning is a learning approach where students are faced with authentic problems so that they are expected they can compile their own knowledge, develop high-level skills and inquiry, empower students and enhance their confidence. PBL which start with observing real problems in the field related to the digestive system, then students formulate problems, determine work procedures for solving problems, solving problems, conclusions.

The learning outcomes are the achievement of students' abilities, after the learning process with and without applying the problem based learning (PBL) learning model, to determine student achievement in the form of using a class average measurement using PBL or not.

2.3 Population and Samples

2.3.1 Population

The population in this study were all students of class VII Masinop, Makakalikasan, Maasahan and Masipag 2.3.2 Sample

The samples in this study were all students of class VII-Masinop which amounted to 53 and VII-Maasahan totaling 50 students.

2.4 Research Procedures:

Conducting a pre-test on class VII Masinop, Makakalikasan, Maasahan and Masipag. The pre-test got two classes with the initial average not much different, namely class VII-Masinop and class VIIMaasahan

Determining the control class and experimental class. This determination was done with input from the Coordinator Teacher and the results of the control class VII-Maasahan and class VII-Masinop 2.5 Data Collection Techniques
Observation, carried out by directly observing the learning process in the control class and experiment with power point media and presentation videos.

Tests are conducted to measure learning outcomes. The test consists of two types, namely the initial test (pretest) to find out the student learning outcomes before applying the treatment, and the final test (posttest) to determine student learning outcomes after the treatment is applied.

\section{RESULTS AND DISCUSSION}

Observations indicate that learning in Indonesia is very different from learning in the Philippines. In addition to learning, the habits of students and class hours are very different from in Indonesia. After observing, the habits and teaching and learning process in the Philippines is very different, in the Philippines only requires 1 hour of study in each subject while in Indonesia it takes around 2 hours in 1 lesson. For the process of teaching teachers tend to use the lecture method and less use of electronic media in learning, besides that in the learning process using loudspeakers due to the crowded and crowded classroom atmosphere and teachers still teaching with unfavorable conditions.

This is different from the condition when I (the Indonesian teacher taught). The students tend to be more calm because of the use of different methods. I use more learning media such as power points, photos, videos and games in the learning process. Visible students are more active and tend to pay attention when learning takes place. In addition, there is a bad habit, that is missing, namely raising the foot to the chair during the learning process. Teachers in the Philippines tend to let students lift their feet to a chair, but when I teach I teach not to raise my feet on a chair, and as long as I teach there are no students who raise their feet to a chair. In addition, the use of learning methods also affects the activeness and learning outcomes of students. When teaching, I use Problem Based Learning (PBL).

The results of this study shows that the experimental class average significantly 
differ from control class average. The experimental class is higher than the control class, it can be interpreted that PBL model can make the outcome of learning better.

The implementation of learning in the experimental class with the problem based learning (PBL) learning model with media power points runs through the procedures established in the lesson plan where the teacher's initial activities provide apperception and motivation, then by conveying the topic of learning and learning objectives after learning for 5 minutes. The teacher provide 10 minutes of short learning related to material that need to be considered in solving the problem. At the core of learning activity for 25 minutes the teacher as the facilitator and moderator, both in the discussion activities and in the activities gives the opportunity to ask students at the end of the core activities. In the last 10 minutes, the teacher gives conclusions and posttests to students and is collected when the class ends. After the teacher gives an assessment of the level of organization and is collected the next day before the lesson begins.

The implementation of learning in classroom treatment with learning uses direct learning models with power point media and video presentations run through the procedures set out in the lesson plan where the teacher's initial activities provide apperception and motivation, then by conveying the topic of learning and learning after learning for 5 minutes. Then it was suggested by a posttest of cells to organism and an explanation of cells to organism and the post-test discussion for 10 minutes. Then proceed with the core activity, namely an explanation of 30 minutes of learning material about cells to organism and in the final 10 minutes posttest is given until the class ends and then is collected to the teacher.

Student learning outcomes based on the results of the pretest and posttest shows that student learning outcomes on experiment class, higher than on control class. The pretest in the experimental class had an average of 65.4 and the posttest were 88.6. While in the control class, the pretest showed results of 67.82 and the posttest results were 81.9 . The results of this study are in line with the following literature which states that the results of this study support the results of research Roth (1994), and Brown (2003) that the tasks carried out in groups will improve cognitive learning outcomes of students or students with low and high initial abilities, because through assignments groups of students gain a comprehensive understanding of the results of discussions with peers.

According to Woods (2000) quoted by Amir (2013: 13), that "Problem Based Learning (PBL) can help students build skills throughout their lives in solving problems, teamwork and communicating". Dewey's view that schools must be a laboratory for solving real life problems provides a philosophical foundation for PBL (Arends, 2012: 400). PBL syntax according to Arends (2008: 57) consist of five stages, but PBL also has weaknesses including without understanding why they are trying to solve the problem being studied, so they will not learn what they want to learn and when students do not have the intention or do not have the belief that the problem being studied is difficult to solve, then they will feel hesitant to try (Sanjaya, 2007: 27). Contextual learning in learning applied through the problem based learning (PBL) learning model aims to equip students with knowledge that can be flexibly applied (transferred) from one problem to another and from one context to another (Ministry of National Education, 2002).

The abilities that students need to have include problem-solving skills. Problem solving ability according to Wena (2011: 53) is very important for students and their future. The ability to solve problems according to Simamora (2014: 3) is the ability shown since recognizing problems, finding alternative solutions to problems, choosing an alternative as a solution, and evaluating the answers that have been obtained. The ability to solve this problem also needs to be possessed by students in biology, because to be able to solve problems related to nature. Therefore learning with Problem Based Learning (PBL) is very effective applied to explore the potential and ability to think critically in 
students. Contextual learning in this case through the application of problem based learning (PBL) learning models gives a better influence on cognitive learning outcomes. This means that students learn more efficiently when they are allowed to work together (cooperative) with other students in a group or team (Fouts, 1993; Harvey, 1998; Lord, 2001).

\section{CONCLUSION}

Learning outcomes (average posttest) Biology subjects Cells to Organism material in class VII Baguio City National High School, Baguio City, Philippines after the learning process does not apply Problem Based Learning is 81.9. Learning outcomes (posttest average) Biology subject Cells to Organism material at VII Baguio City National High School, Baguio City, Philippines after the learning process applies the Problem Based Learning is 88, 6 . Application of Problem Based Learning (PBL) in Biology learning influences the biology learning outcomes of VII Baguio City National High School students, Baguio City, Philippines.

\section{REFERENCES}

Amir, Taufiq. 2013. Educational Innovation Through Problem Based Learning. Jakarta: Kencana Prenada Media Group.

Arends, RI 2008. Learning to Teach. Learning to Teach. Seventh edition. (Translator: Prayitno and Mulyani). Yogyakarta: Student Library.

BCNHS. 2018. https://www.edukasyon. $\mathrm{ph} / \mathrm{schools} /$ baguio-city-nationalhigh-school (accessed September 5, 2018)

Buchanan, Lisa Brown. 2012. Creating Critical Conversations: Investigating the Utility of Socio Dialogues in Elementary Social Studies Methods. Teacher Education and Practice. 25 (2), 221-234
K12Philippines. 2018. http://k12 philippines.com/ (accessed on September 5, 2018)

Magdalena, Rita. 2015. Application ofLearning Model Problem based Learning (PBL)and Its Effect on Biological Learning Outcomes of Students of Samarinda City High School 5 Class XI Academic Year 2015. Proceeding Biology Education Conference (ISSN: 2528-5742), Vol 13 (1) 2016: 299- 306

Republic of Indonesia Minister of Education and Culture Regulation No. 21. 2016. Regarding the Standards of Content for Primary and Secondary Education. Retrieved 5 September 2018 from http://bsnpindonesia.org/?page_id=103/.

Sanjaya, Vienna. 2007. Learning Strategies (Educational ProcessOriented Standards). Jakarta: Kencana Prenada Media Group.

Sanjaya, Vienna. 2013. Education-oriented Learning Strategies for Education Processes. Jakarta: Kencana Prenada Media Group.

Trianto. 2010. Construtivistic Oriented Learning Models. Jakarta: Library Achievement. 